\title{
SOME CRITERIA OF A LEXICAL QUANTOR TYPOLOGY
}

\section{Bialyk V. D.}

\section{INTRODUCTION}

The modern stage of the development of cognitive science is marked by linguists' interest in the issues of language knowledge representation in terms of language means, where language is viewed as a sign system. Human cognition is the subject-matter of cognitive linguistics, the latter being treated as interaction of the systems of perception, presenting, and producing information in a word. This fact requires introducing a new term which could serve the purposes of cognitive terminology standardization. In the research under consideration we introduce such a term known as a lexical quantor (LQ).

LQ is viewed as a nominative meaningful informative semiotic unit in the sphere of communication transferring a certain quantum of relevant information/knowledge about the surrounding world in the process of its cognition functioning at the same time as an operator of language world view (LWV). Thus, the information factor (quantum of information LQ represents) and functioning as an operator of LWV in spatial and temporal coordinate system (quantum+operator $=$ quantor) are the vital prameters of LQ as a linguocognitive unit. These basic characteristics of LQ cannot be ignored while dealing with its ontology.

The very ontology of LQ implies establishing some taxonomical criteria.The taxonomical criteria help to structure language knowledge and present it in the form of some system. The system is of paramount importance because it lies in space as an explication of local presentation of various notions ${ }^{1}$. Nowadays localism underlies cognitive linguistics implying spatial representation of knowledge.

In this paper we propose two criteria to be considered, namely: the language knowledge evolution criterion, and 2) the language space criterion. The choice is much stipulated by the aforementioned factors that LQ is viewed as a linguocognitive unit transferring a certain quantum of knowledge about the language reality, on the one hand, and its active part in quantifying (dividing) the language reality by verbal means as an operator of the LWV, on the other.

${ }^{1}$ Болдырев Н.Н. Язык и система знаний. Когнитивная теория языка. М. : Издательский Дом ЯСК, 2018, C. 10. 


\section{Language Knowledge Evolution Criterion}

LQ as a verbalized quantum of the language knowledge is characterized by its dynamic development which is conditioned by the very language knowledge evolution itself and the dynamics of language changes. These transformations are reflected in a lexical neoquantor (LNQ) as a verbalized marker of new knowledge (added-on or modified). The study of various stages of LNQ development and its types results in the differentiation of these types as they transfer new knowledge about the surrounding reality in terms of lexical innovations. The main properties underlying this differentiation in the process of establishing LQ types are: linguistic nature, reproductivity, individual character, synchronous and dichronous diffusion, word-formative productivity, original disposability, contextual dependence, novelty of a lexical meaning, expressivity, and nominative optionality. These properties have been determined on the basis of the research done by such outstanding linguists as V. Zabotkina, Y. Zatsny, O. Zemskaya, E. Kubryakova, A. Levitsky, O. Lykov, O. Rebriy, M. Shanskiy and others.

$L Q$-noncewords. At the stage of creating new knowledge about the surrounding world a speaker usually designates one of the elements of a certain sphere of his/her activity and, thus, renders a certain amount of knowledge about this very worldview segment. This LQ stage is known as the stage of forming a nonce-word, which is characterized by original disposability, non-normativity, and expressivity. The nonce-word usage may be considered as the moment of utmost strenuous activity of a human thinking process in relation to the adequate world perception ${ }^{2}$. Obviously, LNQ arises due to pragmatic reasons. There is a need to name something which is not reflected in the language and, thus, it does not have any equivalent in it. Therefore, there arises a speaker's intention to surprise the interlocutor or influence his/her feelings, emotions, and views. This accounts for individual characteristics of a personality being involved in the process of the LNQ formation. So, at the initial stage of new knowledge formation a neoquantor possesses the property of an individual characteristic.

\footnotetext{
${ }^{2}$ Бялик В.Д. Неологизмы, окказионализмы, реалии в оригинале и переводе романа В. Набокова “Лолита”. Крымский Набоковский научный сборник. Симферополь : “Крымский архив”, 2003. Вып. 3 : Проблемы синтеза в культуре, С. 15-23.

Бялик В.Д. Проблеми диференціації оказіоналізмів та неологізмів. Мови у відкритому суспільстві : матеріали V регіональної наук.-практ. конф. (Чернігів, 24-25 верес. 2004 р.) / М-во освіти і науки України, Чернігів. держ. пед. ун-т ім. Т.Г. Шевченка. Чернігів : Віст-сервіс, 2004. С. 8.

Бялик В.Д. Еволюція лексичного квантора у мовній картині світу. Актуальні проблеми філології та перекладознавства : зб. наук. праць. Хмельницький, 2006. Вип. 2. С. 17-19.

Бялик В.Д. Епістемологія лексичного квантора : монографія. Чернівці : Золоті литаври, 2012, 420 с.
} 
Though the term "nonce-word" has been widely used in linguistic literature, we should admit that there is no unanimity as for its definition. For instance, N. Feldman among the basic properties of a nonce-word distinguishes its absolute novelty, context dependence, and lack of dictionary fixation $^{3}$. A. Lykov also emphasizes context dependence as a vital characteristic of a nonce-word, asserting that it is realized in a specific speech usage $^{4}$. Meanwhile, O.Akhmanova understands a nonce- word as a word or a phrase used only once for a specific purpose", thus, pointing out its disposability ${ }^{5}$. According to M. Shanskiy, the basic property of a nonce-word is the lack of its reproductivity ${ }^{6}$. Other linguists try to oppose nonce-words to neologisms, the latter being language facts ${ }^{7}$. Still other scholars oncentrate on structural and functional properties of lexical innovations ${ }^{8}$. While the linguists are still arguing as for normativity/non-normativity of a nonce-word as a LQ-occasionalism, it is quite obvious that a new lexical formation is aimed at transferring new knowledge and is represented by LNQ.

Undoubtedly, on the background of the speech process usage, LQ-nonceword is not a fixed language fact but in most cases they are formed in accordace with the existing word-formation patterns or by analogy. So, we can state that LQ-nonceword is a lexical unit formed in speech with a certain purpose (intention) in a certain situation. The majority of scholars do not consider such words to be language facts. Despite the debates as for the LQ-nonceword definition and various approaches to solve the problem, it is quite clear that such a lexical formation is a LNQ which serves to render new information/knowledge about a certain element of reality in a specific situation realizing the addresser's intention. From this point of view LQ-nonceword is a nonnormative when taking into consideration its "strange" new meaning of its components, its semantics, and inconsistency of its usage at the stage of its arising. This LNQ "strangeness" is the result of its expressivity, its impact on the thoughts and feelings of the interlocutor, forming a unique speech

\footnotetext{
${ }^{3}$ Фельдман Н. И. Окказиональные слова и лексикография. Вопросы языкознания. 1957. № 4. С. 15-24.

${ }^{4}$ Лыков А. Г. Окказиональное слово как лексическая единица речи. Филологические науки. 1971. № 5. C. $70-82$.

Лыков А. Г. Современная русская лексикология (русское окказиональное слово) : учеб. пособие для филол. фак. ун-тов. М. : Высш. школа, 1976.

5 Ахманова О. С. Словарь лингвистических терминов. (Около 7000 терминов) / О. С. Ахманова. [2-е изд. стереотип.]. М. : Сов. Энциклопедия, 1998, С. 95.

${ }^{6}$ Шанский Н.М. Русский язык. Лексика. Словообразование.М. : Просвещение, 1975.

${ }^{7}$ Земская Е.А. Окказиональные и потенциальные слова в русском словообразовании. Aктуальные проблемы русского словообразования : [в 2 ч.]. Самарканд, 1972. Ч. 1. С. 19-27.

Земская Е. А. Словообразование как деятельность / Е. А. Земская. М. : Наука, 1992, С. 44.

8 Ребрій О. В. Оказіоналізми в сучасній англійській мові (структурно-функціональний аналіз) : автореф. дис. на здобуття наук. ступеня канд. філол. наук : спец. 10.02 .04 “Германські мови”. Х. : Харків. держ. ун-т., 1997.
} 
situation. LNQ-noncewords usually differ from LNQ-neologisms by preserving their novelty irrespective of the time of their arising.

The context dependence property is also a vital characteristic of a LNQ-noncewords. They are created by a speaker accidentally and are used primarily only in the context they appeared in. Hence, the context plays a major role in decoding the meaning of a new-formed LNQ. Still, we must admit that the meaning of a LNQ is often not revealed only by the context. There should be other factors involved in the process, among them wordformation patterns, semantic and structural relationship of word components and so on.

LQ-potential word. We share the opinion of O. Zemskaya that a nonce-word used in speech recurrently by different speakers may acquire the property of potentiality (italicized by me - V.B.), thus taking a higher level of its existence ${ }^{9}$. At this stage a lexical unit has not been fixed by a word usage tradition and there is a potential / probability to be used recurrently as a language fact to render a certain information under specific contextual conditions, Such a situation occurs when a certain LQ-nonceword is a socially actualized phenomenon. It is quickly adapted, spread, and received by the community as a full fledged lexical unit.

A potential word is another type of LNQ. There are several types of potential words in linguistics which differ in the ways of their formation. We believe that all these types share one important feature: they can acquire the status of LNQ-neologisms and replenish literary wordstock.

A potential word, the meaning of which is a sum of its components meanings, embodies the realization of a word-formation type. It is believed that a potential word is understood beyond the context, it may be created by any speaker, or it may be created by different speakers independently ${ }^{10}$. A speaker more often than not designates something lacking a fixed naming. In dictionaries, potential words are usually marked as possible derivatives the meanings of which are clear as they realize the already existing pattern.

Very often there arise words in speech which, at first sight, do not express any new information, do not serve to designate new concepts or ideas but render the notions already existing in the language, though these already existing notions are rendered differently, by different linguistic means, say words instead of word combinations (blacksploitation exploitation of black people by others; shweater - sweater with a shirt-like collar).

\footnotetext{
9 Земская Е. А. Окказиональные и потенциальные слова в русском словообразовании. Актуальные проблемы русского словообразования : [в 2 ч.]. Самарканд, 1972. Ч. 1. С. 19-27.

10 Зубкова Л. Г. Принцип знака в системе языка / Л. Г. Зубкова. М. : Языки славянской культуры, 2010, 752 c. (Studia philologica).
} 
Such formations are not fixed in dictionaries, as a rule. As they do not express new concepts, O. Akhmanova determines them as derivatives or compounds which do not exist in reality, are not fixed in dictionaries but may be created at any time in accordance with the productive word-formation patterns of a certain language ${ }^{11}$. We consider such words to be LNQ-creature which still render a new creative information/knowledge about the existing element of reality, or, in other words, express in a new way the already existing facts in the language. On the one hand, such formations are conditioned by stylistic needs of speaking, on the other hand, by the desire to creatively represent oneself in the process of speech communication or designate the notion with one word (univerb) instead of its description with a word combination. These are the words that are considered to be potential.

The main peculiarity of potential words is the possibility to reproduce themselves (reproductivity), though another important characteristic is their semantic transparency (high level of motivation): The meaning of the whole in a potential word is usually a sum of its components meanings ${ }^{12}$. For example, buttmunch (composed of: 'butt' (to hit something with the head) + 'munch' (to eat food loudly)), awesome-itude (awesome+magnitude), etc. Still another peculiarity of potential words is their correlation with free word combinations (e.g., twenty-four-seven (24/7) in a sentence I feel like I study twenty-four-seven), they can be easily interchanged and used in the same context.

At the potential stage of its development LNQ possesses a number of properties. First and foremost, it is its affiliation with language and creativity. Secondly, all types of LNQ, and LNQ-potential word is not an exception, are characterized by word formation productivity (stillnessway, abroadness, courseware). It sould be mentioned that potential words as a type of compound words may be represented not only by nouns but also adjectives as a result of the transformation of the syntactical construction of the type cyber-grounded-grounded in cyberspace. Sometimes we may trace the transformations based on different construction types: just-in-time lifestyle, do-it-herselfer, etc.

Thirdly, a LNQ-potential word likewise a LNQ-nonceword is characterized by specific disposability. It is not clear at the initial stage of its formation whether it will become a language fact.

$L Q$-neologism. The realization of the language system potential in the formations of the nonce word or potential word types may result in

\footnotetext{
11 Ахманова О. С. Словарь лингвистических терминов. (Около 7000 терминов) / О.С. Ахманова. [2-е изд. стереотип.]. М. : Сов. Энциклопедия, 1998.

12 Царев П. В. Потенциальная лексика в современном английском языке. Иностранные языки в школе. 1978. № 1. C. 22.
} 
acquiring the status of a neologism due to the expansion of the sphere of its usage. We believe that nominal optionality plays a decisive role in the process $^{13}$ and determines the stage of potentiality of LNQ marked by the nominal optionality property. A new word is on the crossroad of a nonce word and a potential word, on the one hand, and neologism, on the other. If such a nomination is necessary, then it might become a language fact, but if it remains as "possible", then its status is fixed at a speech level. And only the language community can influence the choice of a dominant, the necessity to realize this or that nomination, to be exact. With the multivectoral development of the society it is necessary to adequately represent new elements of reality in LWV. This results in coining new nominations and modifying the existing ones. The evolution of the society goes hand in hand with the language knowledge evolution embedded in LNQ.

Generally, in linguistics it is a common knowledge to define neologisms as new lexical units which appeared due to the needs of the society to name new objects or express a new notion. The neologisms traditionally function in language as reproducible ready-made lexical units. As a rule, a neologism is a word or a word combination which has appeared in language recently. It should be noted how important a temporal criterion is as for neologisms. A neologism is closely related with the timeline and remains a new lexical formation as long as it keeps the novelty connotation. This generally accepted idea of a neologism in linguistics is not deprived of some subjectivity, inaccuracy, and obscurity.

The dynamics of language knowledge, in particular, as the dynamics of a lexical system of the language, in general, is manifested in evolution of lexical units from speech to language. LNQ-neologisms first come into language as speech units (LNQ-noncewords) acquiring some potentiality with time so that later to be fixed in dictionaries as language facts. To understand the notion of "neologism" we suggest three criteria to be considered. They are as follows: temporal, affiliation/non-affiliation with language, and novelty connotation. We do understand that these criteria are rather of relative and diffused nature. In broad sense a "neologism" is treated as a general term for speech and language formations.

\footnotetext{
${ }^{13}$ Бялик В. Д. Неологізми в ситуативній моделі перекладу. Мовні і концептуальні картини світу : зб. наук. праць. К. : Видавничий Дім Дмитра Бурого, 2004. Вип. 11. Кн. 1. С. 68-71.

Бялик В. Д. Особливості перекладу англійських неологізмів. Науковий вісник Чернівецького університету. Германська філологія : зб. наук. праць. Чернівці : Рута, 2004. Вип. 206-207. С. 360-369.

Гак В. Г. К типологии лингвистических номинаций. Языковая номинаџия. Общзе вопросы. М.: Наука, 1977.

Гак В. Г. О современной французской неологии. Новые слова и словари новых слов. Л. : Наука, 1978. C. $37-52$.

Жлуктенко Ю. А. Английские неологизмы. [под ред. Ю. А. Жлуктенко]. К. : Наукова думка, 1983.
} 
We tend to think that the definition of a neologism offered by N. Kotelova is classical and most exhaustive. According to this scholar, neologisms are new, first created or borrowed from other languages words, or the words known earlier in the language but with limited usage, beyond the boundaries of a literary norm, or the words not actively used before but active at the given moment, as well as derivatives, potential words formed on the basis of already known words in accordance with the established word-formation patterns ${ }^{14}$.

This definition, actually, stands for LNQ in our treatment of a LQ from the cognitive aspect, i.e. what type of language information/knowledge it represents. As the formation of neologisms is aimed at nominating new objects, phenomena, or ideas, it embodies new language knowledge represented by LNQ. Analysing the aforesaid definition, we can single out the basic properties of LQ-neologism, namely: affiliation with language, word-formation reproduction, contextual independence, and novelty. The property of novelty is of not constant character. With time, the novelty may remain or disappear, being only topical for a speaker within the period he/she lives in. As for LQ-noncewords and LQ-potntial words, which have not become language facts, they are characterized by synchronous and diachronous diffusivity. Such formations, as a rule, do not correlate with historical timeline but still are the innovations due to their lexical meaning or semantic characteristic. In other words, this type of LNQ is not deprived of its novelty and uniqueness despite being not regularly reproducible.

When a speaker creates a verbalized marker for new knowledge presentation, he/she tries to make it most expressive. That is why LNQ has a form of a specific independent lexical unit. The LNQ meaning, as fixed in a dictionary, may differ from its original, specific meaning which it used to have with the status of LNQ-nonceword; the sphere of its usage may change too. The expressive and stylistic function of a LNQ is substituted for the normative and informative function in LNQ-neologism. This is the reason why a potential word or a nonce word loses its expressivity retaining only its novelty for some time.

Summing up, we can assert that various LNQ types may be distinguished by the following properties: affiliation with language or speech, reproductivity, individual nature, synchronous and diachronous diffusivity, word-formation potential, disposability, context dependence, lexical meaning novelty, expressivity, nominative optionality. So, LNQ expressed by a nonce word or a potential word is affiliated with speech

\footnotetext{
${ }^{14}$ Котелова Н. 3. Первый опыт лексикографического описания русских неологизмов. Новые слова $и$ словари новых слов. Л. : Просвещение, Ленингр. отд-е, 1978, С. 24.
} 
rather, while LNQ-neologism is definitely correlated with language facts. LNQ represented by nonce words and potential words are characterized by their expressivity, individuality, nominative optionality, context dependence, disposability, synchronous and diachronous diffusivity. Meanwhile LNQ-neologism, as a language fact, is deprived of expressivity, context dependence, acquires nominative informativity and is characterized by multiusage in language.

The potential of LNQ, to our mind, may be realized in two ways: according to the first one it may remain a real non-existent possibility, while in the second case this possibility may be realized and embedded in LNQ-nonceword. LNQ-nonceword, in its turn, is also realized twoways: when a word is not accepted by the language community and is disposable, i.e. created for one-time usage, it remains a nonce word or a potential word. In the second case, if a word is fixed in a dictionary it acquires the status of a neologism and, thus, becomes a language fact. The possibility is encoded in LNQ, and at the stage of its realization the occasional and the potential may overlap resulting in a nonce word or a potential word formation. So, LNQ is formed in speech and has good chances for potential development acquiring, as a result, the status of LNQ-neologism.

Thus, the LNQ notion embraces all the properties of lexical innovations starting with its genesis, realizing the potential possibilities of a language in accordance with specific speech needs, and all stages of new knowledge formation starting from the coining a new word by a speaker in a certain communicative situation and developing into a full fledged lexical unit due to the potential of a language system. Thus, at different stages of its development LNQ is represented by a nonce word, a potential word, and a neologism. From the historical aspect of LNQ development, a new word designating new knowledge may be created by any speaker but its undividuality loses its importance with time and usage sphere expansion. The status and the degree of a creator's/speaker's importance depend on LNQ level development: the level of speech or the level of language.

It remains a LNQ-nonce word and realizes potential possibilities of a word stock of a given language till it functions at the level of speech. A speaker who coins a new word strives for individuality and originality. This is where the creative factor of a language personality is manifested most of all. In the process of its development LNQ passes through some stages; specialization (acceptance by the community) and lexicalization (fixation in language). This process is closely associated with four levels of new knowledge realization in LNQ; the personality level, the social group level, the media level (newspapers, TV, etc.), the dictionary fixation. 
The LNQ development process (from occasional word formation to neologism) envisages the stage development and approbation of a new word in language. It is formed accidentally and being at the disposal of the community loses its disposability and a creator but still retaining novelty for some time as it is time-dependent. It is up to further usage and actual necessity of a lexical unit that it may change its realization status transferring from a fact of speech to a fact of language, when a new word may be fixed in a dictionary of neologisms as a new linguistic unit designating new knowledge.

$L N Q$ vs. LQ-conventional word. LQ as presented by a conventional word is a historically fixed in language sign of a certain reality and in living speech is the reflection of such reality. A certain word of language in an appropriate situation is a nominative, obligatory fact in conformity with a lexical system and a language norm at a certain span of time and space continuum. A conventional word reflects linguistic generally known, socially determined meaning fixed by usage and norm. On the contrary, the violation of such norms is observed in LNQ which is due to both linguistic and extralinguistic factors. This is the evidence of the dynamics of a lexical system representing a certain LWV.

The LNQ genesis, to our mind, is much stipulated by a speaker's intention as it is not mere the cognition of a speech situation but also speaker's intention to change it according to his/her needs. This need activates the conscience of a speaker and serves its stimulus, impact of thought generating process. The very LNQ formation is much due to its creator. It he/she who selects from inner lexicon available the best what reflects his/her thoughts and feelings, and renders a quantum of information in accordance with the speaker's intention. If there is no such a word in a speaker's lexicon, he/she modifies an alod lexical unit or coins a new one which reflects a modified knowledge in respect to that designated by this lexical unit ealier.

\section{LQ Taxonomy as a Result of Language Space Quantifying}

LQ is characterized by both linguistic and cognitive properties. As it has been mentioned earlier ${ }^{15}$ LQ shares the word properties. It serves to name objects, their properties and characteristics, their interaction, as well as real and virtual notions existing in a person's imagination, i.e. LQ performs a nominative and referential function.

However, being a linguocognitive unit LQ, first and foremost, is characterized by the informative function indicating to the amount of

\footnotetext{
${ }^{15}$ Бялик В. Д. Епістемологія лексичного квантора : монографія. Чернівці : Золоті литаври, 2012.
} 
knowledge/information about language reality. Meanwhile, LQ is also an operator of the categorization of this reality. It does not only change an object, but analyzes it, correlating it with a complex system of relations and ties. A certain amount of knowledge a LQ contains may be correlated with meaning or sense. Lexical meaning and sense are distinguished in linguistics, as a rule. If LQ meaning is an objective reflection of the system of relations and ties, then sense implies adding-on the subjective aspects of meaning in accordance with a specific moment or situation. In our research these two components of language knowledge (meaning and sense) will help reflect the appropriate amount of knowledge in LWV segment in the process of cognitive activity of a person. With this approach we may assert that sense and meaning may be viewed as identical with language knowledge. Here we can clearly trace the interaction of the three elements of the cognitive process of a person which are realized in the triad: sign : meaning : knowledge. A linguistic sign stands for some meaning indicating to some knowledge about the corresponding segment of LWV.

Undoubtedly, LQ may be considered as the system of codes ensuring the transference of the human's cognition into new dimension which allows to make a leap from the sensual conditioned by a direct contact with outer world through feelings, perception and imagination to the rational expressed by thought, abstract thinking which is realized in notions and judgments. In other words, LQ is a verbal representative of knowledge/information about the surrounding world (or rather its segment) on the basis of sensual perception and as a result of abstraction of the acquired experience and its rendering in a verbal form.

It is a very complex process which involves both psychophysiological and linguistic proper mechanisms. This complexity is reflected on the very LQ classification which is manifested at various language levels (phonetical, word-formational, semantic, etc.) and extralinguistic level (time, space, language personality).

This is the very aspect of considering the criteria of LQ typology and establishing the principles of its classificartion. As LQ versatility and multi-facetness are expreseed both in its typology and in singling out the criteria of its classification, the major task is to ouline the most essential parameters which can reflect LQ ontology. This undertaking requires singling out only those criteria which could best indicate to the availability of information about the objects and phenomena of the surrounding world represented by LQ as a marker of verbalized knowledge. Such markers may be represented by the constituents of LQ content structure and indicate to its word-formation pattern and its semantic expansion in spatial and temporal continuum. 
Proceeding from the cognitive nature of LQ it is expedient to single out, at least, basic criteria of LQ classification which seem to be most vital, such as: part-of-speech (morphological) criterion, formant criterion, semantic criterion, temporal and spatial criterion.

Morphological LQ. Morphological criterion of LQ types singling out is aimed at reflection of lexico-grammatical division of language continuum and lexical means of reflection of of non-language reality. While applying this criterion, it is reasonable to take into consideration, at least, three aspects of LQ, namely: LQ meaning, its form, and fuction. The LQ meaning in accordance with this criterion is a lexical category and indicates to the meaning of the whole group of words, namely: substantivity, action, property, state, manner of action and what on.

The LQ form within this criterion is its morphological characteristic while the LQ function indicates to the collocational properties of LQ, their syntactic functions in proposition. It looks important, to our mind, to take into consideration onomasiological properties of LQ. They indicate to LQ ability to be nominative signs, sign-names intended for reflecting the division of the surrounding reality by a person in accordance with nature of things in parts of speech. Thus, the main feature of a morphological criterion is LQ categorization according to lexico-grammatical classes on the basis of grammatical meaning and its formal markers. Consequently, LQ may be represented by LQ-nouns, LQ-adjectives, LQ-adverbs, LQ-verbs, etc. in accordance with this criterion.

Formant $L Q$. The formant criterion of $L Q$ serves to show the complexity of its word-formation structure. The elements of this structure correlate with a minimal amount of knowledge which is in LQ. A formant is understood as a part of a word which is capable to change the lexical or grammatical meaning of a root or a stem and serves for word-formation purposes or a word change. On the basis of this criterion it is possible to distinguish LQ-derivatives, LQ-compounds, LQ-abbreviations. Each of these types may be characterized by some sub-types. Thus, LQ-derivatives may be represented by LQ-prefixates (the element of the structure is a prefix), LQ-suffixates (the element of the structure is a suffix), LQ-prefisufficates (the elements of the structure are a prefix and a suffix at the same time), LQ-coversates (coined in terms of conversion). LQ-abbreviations may be characterized by LQ-letterates (the element of the structure is a letter), LQ-integrates (coined in terms of blending), and so on.

Semantic $L Q$. The semantic criterion indicates to the deep semantic factors and the sphere of its application implies the direct connection of a certain class of words with non-linguistic reality. Such a connection may 
refer to the nucleus of the semantic structure of LQ and may be characterized by the denotative correlation. It may also involve its periphery which indicates to the peculiarities of the surrounding reality presentation which, as a rule, is reflected in secondary nomination process. The semantic criterion is applied to LQ which contain some knowledge/information in their semantic structure gained in the process of the semantic extension of LQ meaning due to the changes in denotative or connotative components, or mechanisms of amelioration and pejoration of meaning. Here we also include LQ the meaning of which as well as the amount of corresponding knowledge is determined in terms of metaphorization or metonimization. Thus, we distinguish LQ-denotatives, LQ-connotatives, and the latter are subdivided into LQ-amelioratives, LQ-pejoratives, LQ-metaphors, LQ-metonyms, etc.

Temporal LQ.As it has been mentioned earlier, LQ representing a certain verbal segment of LWV, first and foremost, is aimed at reflection of the informational constituent about this segment or, in other words, transferring some amount of knowledge in temporal and spatial continuum. This LQ property may be considered as a certain philosophical and linguistic universal truth realized in its categorization in time and space. The temporal parameter of LQ typology determines the following LQ types: LQ-archaism (past, historical knowledge, archaquantor), LQ-conventional word (present, encyclopedic knowledge - conquantor), LQ-nonceword (present and future, creative occasional knowledge), LQ-neologism (present and future, creative established knowledge). As the last two types of LQ are characterized by some linguocreativity aimed at expressing new experience and, thus, new knowledge, they may be considered as neoquantors (LNQ). It is quite clear that such a classification is rather simplified. There are some LQ that may correlate with a certain distance of the timeline (in the past and at present). Consequently, these LQ types, in accordance with the temporal criterion, will reflect one-way (from past to present) knowledge development movement as represented by LQ and correlate with an appropriate span of time continuum. As for the past, LQ presents probable information about an object of the surrounding world. As for the future (and present as in case with LNQ), a new state is formed in it. Taking into account that the states of our world depend on time, the state of any system, and LQ including, also depends on time, as a rule. However, in some cases the dependence of any value may be too weak. In such cases we can assert that this characteristic is irrelevant to temporal parameter. If such values describe the dynamics of the system.

Spatial $L Q$. The temporal parameter is closely associated with the spatial parameter and, more often than not, these two parameters are 
considered as complementary and indivisible. Space is understood as a form of existence of matter, it characterizes its extension, structurality, coexistence and interaction of the elements in all material systems. The general understanding of space is formed on the basis of empirical experience while characterizing a material object or multitude of these objects taking different positions in space.

It is quite obvious that LQ indicates to various spatial relations a language personality is in. LQ represents a certain sphere of human activity determining one of its elements or contains a certain amount of knowledge about this segment of human activity. That is why all possible spheres of an individual activities (politics, medicine, science, technology, meals, etc.) contain quanta of knowledge lexically marked and expressed in LQ.

LQ typology in accordance with the spatial criterion involves a certain language space realized in LQ reflecting some segments of the surrounding world. The basic types of human activity due to this criterion may be represented by the following LQ inventory involving politics, entertainment, sports, arts, science, education, mass media, law, economics, and environment.

In the research we made an attempt to classify neoquantors employing the criterion in question with reference to new words as fixed in lexicographic sources ${ }^{16}$. As a result of the analysis performed it was possible to single out the following LNQ types: LQpl - politics, LQbe business, economics, LQsl - sports, leisure, LQae - arts, entertainment, LQse - science, education, LQmd -medicine, LQmt - military, war terrorism, LQev - environment, LQgm - meals, drinks, food, LQmc - mass media, communication, radio, TV, press, LQid - instrument, device, gadget, LQit - innovation technology, Internet, software, computing, LQtc - technology, transportation, LQsc - social relations, group of people, organization, LQlg - logic relations, abstract notions, LQpr process, motion, action, LQag - agent, performer, doer, LQch characteristics, property, quality, quantity, state, status, LQml - mode of life, style of life, LQcr - crime, drug abuse.

\section{CONCLUSIONS}

The research has shown that LQ is characterized by a complex hierarchy of relations of its content structure that identifies a corresponding quantum of knowledge which correlates with a certain segment of LWV. It is necessary to take into consideration all possible ways of LQ expression by various criteria for objective representation of knowledge in

\footnotetext{
${ }^{16}$ Twentieth Century Words. John Ayto. Oxford : Oxford University Press, 1999.
} 
LQ on, basically, two principles: the evolution of language knowledge and its spatial representation by verbal means.

According to the first principle LQ may be classified on the basis of language knowledge evolution ranging from new to conventional knowledge (nonce-words, potential words, neologisms, conventional words).

Proceeding from the linguicognitive nature of LQ the basic criteria according to language space quantifying, are as follows: part-of-speech, formant, semantic, temporal, and spatial.

The morphological criterion suggests the categorization of LQ in accordance with lexico-grammatical classes on the basis of its grammatical meaning and formal markers. Thus, LQ are divided into LQ-nouns, LQ-adjectives, LQ-adverbs, LQ-verbs, LQ-pronouns, etc.

The formant criterion indicates to the complexity of its wordformation structure, the elements of which correlate with the amount of minimal knowledge contained in LQ. On the basis of this criterion LQ are divided into LQ-derivatives, LQ-compounds, LQ-abbreviations. Each of the aforementioned types may be subdivided into some subtypes. Say, LQ-derivatives may be represented by such subtypes as by LQ-prefixates (the element of the structure is a prefix), LQ-suffixates (the element of the structure is a suffix), LQ-prefisufficates (the elements of the structure are a prefix and a suffix at the same time), LQ-coversates (coined in terms of conversion). LQ-abbreviations may be characterized by LQ-letterates (the element of the structure is a letter), LQ-integrates (coined in terms of blending), and so on.

The semantic criterion embraces LQ which contain some knowledge/information in their semantic structure gained in the process of the semantic extension of LQ meaning due to the changes in denotative or connotative components, or mechanisms of amelioration and pejoration of meaning. It has been proved reasonable to include in this group LQ the meaning of which as well as the amount of corresponding knowledge is determined in terms of metaphorization or metonimization. Thus, as a result of the research performed, the classification also includes LQ-denotatives, LQ-connotatives, and the latter are subdivided into LQ-amelioratives, LQ-pejoratives, LQ-metaphors, LQ-metonyms, etc.

The temporal parameter is closely associated with the spatial on. These two criteria are viewed as complementary and inseperable.

According to the spatial criterion LQ represent language space that is realized in them and verbalize certain segments of the surrounding world and activity space of a person. 
The suggested principles and criteria of LQ typology may be further applied in the analysis of cognitive properties of LQ both in cognitive fuctional and cognitive -discursive studies.

\section{SUMMARY}

The article dwells on the problem of classification of lexical quantors (LQ) from a perspective of cognitive linguistics which implies human cognition as its subject-matter with the major task to study interaction of the systems of perception, presenting, and producing information in a word.

LQ is defined as a lexical unit represented by a word or word combination conveying some amount (quantum) of information or knowledge about the surrounding world or its segment acting as a worldview operator.

It has been suggested that LQ taxonomy should be based on, at least, two major principles: the language knowledge evolution criterion, and 2) the language space criterion. The choice is much stipulated by the aforementioned factors that LQ is viewed as a linguocognitive unit transferring a certain quantum of knowledge about the language reality, on the one hand, and its active part in quantifying (dividing) the language reality by verbal means as an operator of the LWV, on the other.

According to the first principle LQ may be classified on the basis of language knowledge evolution ranging from new to conventional knowledge (nonce-words, potential words, neologisms, conventional words).

Proceeding from the linguicognitive nature of LQ the basic criteria according to language space quantifying, are as follows: part-of-speech, formant, semantic, temporal, and spatial.

The suggested principles and criteria of LQ typology may be further applied in the analysis of cognitive properties of LQ both in cognitive fuctional and cognitive -discursive studies.

\section{REFERENCES}

1. Ахманова О. С. Словарь лингвистических терминов. (Около 7000 терминов) / О. С. Ахманова. [2-е изд. стереотип.]. М. : Сов. Энциклопедия, 1998, 607 с.

2. Болдырев Н.Н. Язык и система знаний. Когнитивная теория языка. М.: Издательский Дом ЯСК, 2018, 480 с.

3. Бялик В. Д. Особливості перекладу англійських неологізмів. Науковий вісник Чернівецького університету. Германська філологія : 3б. наук. праць. Чернівці : Рута, 2004. Вип. 206-207, С. 360-369. 
4. Бялик В. Д. Неологизмы, окказионализмы, реалии в оригинале и переводе романа В. Набокова "Лолита". Крылмский Набоковский научный сборник. Симферополь : “Крымский архив”, 2003. Вып. 3 : Проблемы синтеза в культуре. С. 15-23.

5. Бялик В. Д. Неологізми в ситуативній моделі перекладу. Мовні i концептуальні картини світу : зб. наук. праць. К. : Видавничий Дім Дмитра Бурого, 2004. Вип. 11. Кн. 1. С. 68-71.

6. Бялик В.Д. Епістемологія лексичного квантора : монографія. Чернівці: Золоті литаври, 2012, 420 с.

7. Бялик В. Д. Еволюція лексичного квантора у мовній картині світу. Актуальні проблеми філологї̈ та перекладознавства : зб. наук. праць. - Хмельницький, 2006. Вип. 2. С. 17-19.

8. Бялик В. Д. Проблеми диференціації оказіоналізмів та неологізмів. Мови у відкритому суспільстві: матеріали $\mathrm{V}$ регіональної наук.-практ. конф. (Чернігів, 24-25 верес. 2004 р.) / М-во освіти і науки України, Чернігів. держ. пед. ун-т ім. Т.Г. Шевченка. Чернігів : Віст-сервіс, 2004. С. 7-9.

9. Гак В. Г. О современной французской неологии. Новые слова и словари новых слов. Л. : Наука, 1978. С. 37-52.

10. Гак В. Г. К типологии лингвистических номинаций. Языковая номинация. Общие вопросы. М. : Наука, 1977.

11. Жлуктенко Ю. А. Английские неологизмы. [под ред. Ю. А. Жлуктенко]. К. : Наукова думка, 1983, 172 с.

12. Земская Е. А. Словообразование как деятельность. М. : Наука, 1992, $221 \mathrm{c.}$

13. Земская Е. А. Окказиональные и потенциальные слова в русском словообразовании. Актуальные проблемы русского словообразования : [в 2 ч.]. Самарканд, 1972. Ч. 1. С. 19-27.

14. Зубкова Л. Г. Принцип знака в системе язика. М. : Языки славянской культуры, 2010, 752 с. (Studia philologica).

15. Котелова Н. 3. Первый опыт лексикографического описания русских неологизмов. Новые слова и словари новых слов. Л.:Просвещение, Ленингр. отд-е, 1978, 72 с.

16. Лыков А. Г. Современная русская лексикология (русское окказиональное слово). М. : Высш. школа, 1976, 119 с.

17. Лыков А. Г. Окказиональное слово как лексическая единица речи. Филологические науки. 1971. № 5. С. 70-82.

18. Ребрій О. В. Оказіоналізми в сучасній англійській мові (структурно-функціональний аналіз) : автореф. дис. на здобуття наук. ступеня канд. філол. наук : спец. 10.02.04 "Германські мови"/ О. В. Ребрій. Х. : Харків. держ. ун-т., 1997. 18 с. 
19. Фельдман Н. И. Окказиональные слова и лексикография. Bопросы языкознания. 1957. № 4. С. 15-24.

20. Шанский Н. М. Русский язык. Лексика. Словообразование. М.: Просвещение, 1975, 239 с.

21. Twentieth Century Words. John Ayto. Oxford: Oxford University Press, 1999, $626 \mathrm{p}$.

\section{Information about the author:} Bialyk V. D.,

Doctor of Philology, Professor, Head of the Department of Communicative Linguistics and Translation, Yuriy Fedkovych Chernivtsi National University 2, Kotsiubynskyi str., Chernivtsi, 58012, Ukraine 